\title{
PEMANFAATAN CITRA LANDSAT 8 UNTUK ANALISIS INDEKS VEGETASI DI DKI JAKARTA
}

The Utilization of Landsat 8 for Analizing Vegetation Index in Jakarta

Siti Novianti Lufilah Mahasiswa Departemen Arsitektur Lanskap, Fakultas Pertanian IPB

Email : noviantilufilah@gmail.com

\section{Afra DN Makalew}

Staf Pengajar Departemen Arsitektur Lanskap, Fakultas Pertanian IPB

Bambang Sulistyantara

Staf Pengajar Departemen

Arsitektur Lanskap, Fakultas Pertanian IPB

\section{ABSTRACT}

In Article 28 of Law No. 26 Year 2007 on Spatial Planning, plan of providing and utilization of green open space are included in the spatial planning aspects of the city, where the extent of at least $30 \%$ of the area of a city. Jakarta which has a total land area of 66.233 hektare achieve, there are currently only $14.94 \%$ of the total extent of which is open space. In support of green open space program, it would require the calculation of the land area of green space appropriately, so that the remote sensing data are increasingly being used to measure green open space. This article presents a study on the utilization of Landsat 8 to analyze the vegetation index using the Normalized Difference Vegetation Index (NDVI). NDVI employs the Multi-Spectral Remote Sensing data technique to find vegetation index, land cover classification, vegetation, water bodies, open area, scrub area, hilly areas, agricultural area, thick forest, thin forest with few band combinations of the remote sensed data. Remote sensing, especially Landsat 8 and geographic information systems (GIS) are used to obtain information about the appearance on the earth surface. From the empirical study, the class of low density vegetation ranged from $0.2343-0.2813$ (36.92\% of vegetation area; $6.31 \%$ of Jakarta area), the class of medium density vegetation ranged from $0.2814-3143(19.03 \%$ of vegetation area; $3.25 \%$ of Jakarta area), and class of high density vegetation ranged from 0.3144-0.6294 (44.04\% of vegetation area; $7.53 \%$ of Jakarta area).

Keywords: geographic information systems (GIS), green open space, Jakarta, Landsat 8, NDVI

\section{PENDAHULUAN}

\section{Latar Belakang}

DKI Jakarta sebagai Ibukota Negara Indonesia mengalami konversi dan konsesi lahan yang pesat setiap tahunnya. Dalam beberapa dekade terakhir, pembangunan fisik di DKI Jakarta terus mengalami perkembangan yang cukup signifikan. Hal ini ditandai oleh pembangunan area permukiman, perkantoran, sarana ekonomi dan sosial, serta infrastruktur kota lainnya. Kecenderungan tersebut mengindikasikan ketersediaan lahan menjadi permasalahan yang penting bagi pembangunan di DKI Jakarta. Selain itu, pembangunan tersebut dilakukan karena lebih memberikan keuntungan secara ekonomis dibandingkan dengan keberadaan vegetasi. Bertambahnya jumlah sarana dan prasarana berdampak terhadap berkurangnya RTH, lahan pertanian, dan hutan kota yang secara otomatis berkurangnya tingkat kerapatan vegetasi. Hal ini tentunya juga akan berpengaruh terhadap keseimbangan ekologi yang ada di wilayah tersebut. Semua ini merupakan konsekuensi logis dari semakin majunya pembangunan dan perekonomian di DKI Jakarta.
Berdasarkan Undang-Undang RI No. 26 Tahun 2007, RTH didefinisikan sebagai area memanjang/jalur dan/atau mengelompok, yang penggunaannya lebih bersifat terbuka, tempat tumbuh tanaman, baik yang tumbuh secara alamiah maupun yang sengaja ditanam. Proporsi RTH pun telah ditetapkan pada wilayah perkotaan, yaitu paling sedikit 30\% dari luas wilayah keseluruhan. Saat ini, RTH di DKI Jakarta masih jauh dari standar ideal tersebut. Berdasarkan data dari Dinas Kehutanan DKI Jakarta, jumlah RTH saat ini mencapai $14.94 \%$ dari luas wilayah DKI Jakarta, atau seluas $9.896,8$ hektar. Dari jumlah itu, sebanyak 5.44\% merupakan RTH publik dan 9.5\% merupakan RTH privat (Martiyanti, 2016). RTH yang kuantitasnya belum mencukupi ini pun sebagian dalam kondisi memprihatinkan, terutama pada RTH pemukiman. Keberadaan undang-undang mengenai penataan ruang tersebut kenyataannya belum sepenuhnya menjadikan RTH di DKI Jakarta sesuai dengan proporsi yang sudah ditetapkan. Kekuatan pasar yang dominan telah mengubah fungsi lahan, terutama RTH yang terabaikan dari segi fungsi dan manfaatnya. Tata ruang yang diharapkan dapat mengakomodasi 
seakan tidak berdaya menahan mekanisme pasar yang lebih mementingkan kepentingan ekonomis (Dwihatmojo, 2010).

Vegetasi sebagai penyusun lahan mempunyai jenis yang sangat beranekaragam. Kumpulan dari berbagai vegetasi yang beranekaragam ini akan menghasilkan tingkat kerapatan vegetasi yang berbeda-beda pada tiap penggunaan lahan di suatu daerah. Tingkat kerapatan vegetasi dapat dikaji melalui penggunaan teknologi yang saat ini terus berkembang. Vegetasi memiliki ciri khas spektral yang unik sehingga dapat dianalisis dengan berbagai cara untuk mendapatkan indeks yang mewakili kondisi dari vegetasi. Teknologi tersebut adalah teknologi penginderaan jauh (remote sensing) dan sistem informasi geografis (SIG). Metode pengukuran vegetasi menggunakan citra satelit memanfaatkan reflektansi dari fitur lanskap.

Penelitian ini dilakukan untuk menganalisis tingkat kerapatan vegetasi penyusun RTH di DKI Jakarta menggunakan data citra satelit Landsat 8 dengan metode Normalized Difference Vegetation Index (NDVI). NDVI merupakan metode standar dalam membandingkan tingkat kehijauan vegetasi pada data citra satelit. NDVI dapat digunakan sebagai indikator biomassa, tingkat kehijauan (greenness) relatif, dan untuk menentukan status (kesehatan/kerapatan) vegetasi pada suatu wilayah, namun tidak berhubungan langsung dengan ketersediaan air tanah di wilayah tersebut (Hung 2000) (Gambar 1). Hasil penelitian ini diharapkan dapat menjadi acuan, terutama bagi pemerintah DKI Jakarta

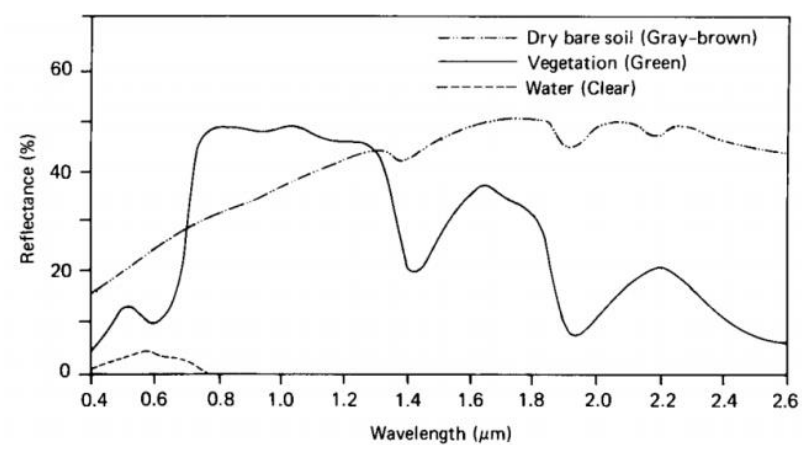

Gambar 1. Kurva karakteristik pantulan untuk vegetasi, tanah, dan air Sumber: Lillesand dan Kiefer (2004)

dalam meningkatkan penyediaan RTH dalam rangka meningkatkan kualitas lingkungan dan mewujudkan pembangunan berkelanjutan di DKI Jakarta.

\section{METODE}

\section{Lokasi dan Waktu Penelitian}

Penelitian ini dilaksanakan di wilayah Provinsi DKI yang secara astronomis terletak pada

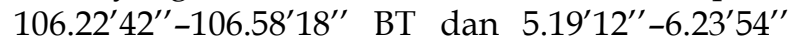
LS. DKI Jakarta memiliki luas total $7659.02 \mathrm{~km}^{2}$ dengan wilayah daratan mencakup $662.33 \mathrm{~km}^{2}$ (66.233 ha). Lokasi penelitian dilakukan di wilayah DKI Jakarta daratan, meliputi lima wilayah Kota Administratif, yaitu Jakarta Utara, Jakarta Timur, Jakarta Selatan, Jakarta Barat, dan Jakarta Pusat (Gambar 2). DKI Jakarta dipilih karena wilayah ini merupakan perkotaan dengan tingkat kompleksitas tertinggi di Indonesia (Sampeliling 2012). Selain itu, DKI Jakarta memiliki tingkat pertumbuhan yang tinggi dalam hal jumlah penduduk, ruang terbangun, perubahan penggunaan lahan, serta penurunan kuantitas RTH. Penelitian dilaksanakan pada Maret 2014 hingga Agustus 2015.

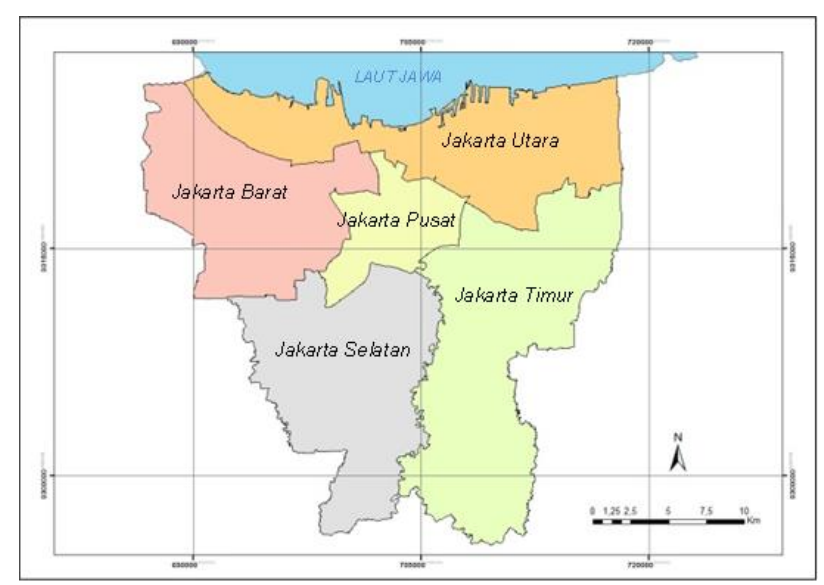

Gambar 2. Lokasi penelitian

\section{Jenis dan Sumber Data}

Penelitian ini menggunakan citra Landsat ETM 8 DKI Jakarta path/row: 122/064, resolusi $30 \times 30 \mathrm{~m}$, akusisi 13 September 2014 yang diperoleh dari The US Geological Survey (USGS) (Gambar 3). Data 
diolah menggunakan perangkat lunak ArcMap 10.3 dan Erdas Imagine 9.1.

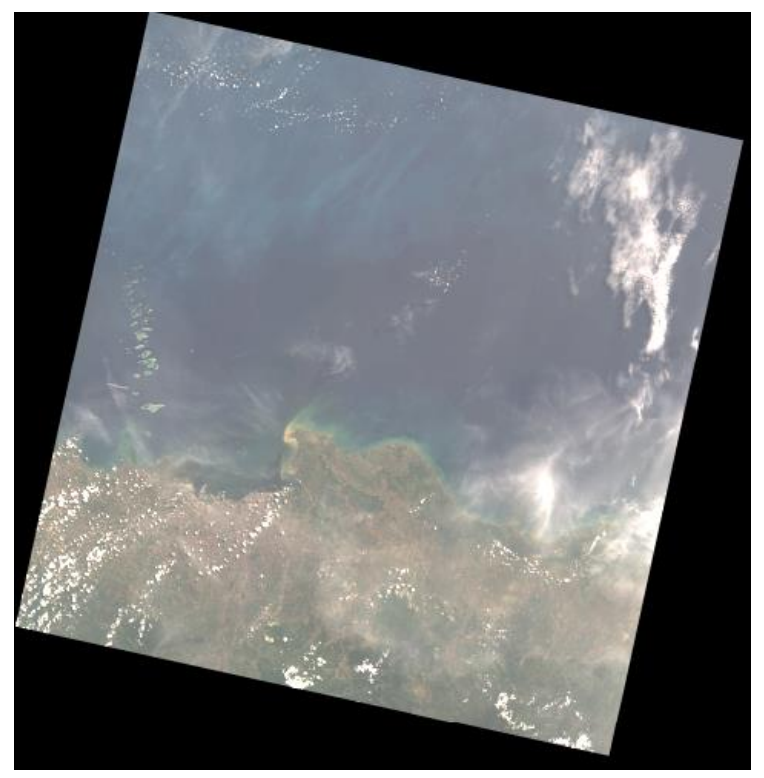

Gambar 3. Citra DKI Jakarta hasil penggabungan band

\section{Metode Penelitian}

Metode yang digunakan dalam penelitian ini adalah deskriptif dengan interpretasi citra Landsat 8, menggunakan sistem informasi geografis (SIG). Penelitian diawali dengan preprocessing data citra Landsat 8 yang meliputi tahap koreksi geometrik dan pemotongan citra (subset image). Selanjutnya data citra Landsat 8 siap digunakan untuk analisis lebih lanjut. Penelitian ini menggunakan metode integrasi antara perhitungan indeks vegetasi Normalized Difference Vegetation Index (NDVI) dengan klasifikasi penutupan lahan menggunakan metode klasifikasi terbimbing (supervised classification) dan Maximum Likelihood. Analisis NDVI digunakan untuk memperoleh nilai sebaran kerapatan vegetasi di DKI Jakarta. NDVI sensitif terhadap aktivitas fotosintesis oleh klorofil sehingga nilai NDVI dapat digunakan untuk membuat klasifikasi vegetasi. Semakin banyak daun dan semakin tebal daun pada tumbuhan maka akan sangat berpengaruh pada hasil pantulannya. Jika terdapat lebih banyak dipantulkan dari radiasi panjang gelombang NIR daripada RED, maka tumbuhan pada area tersebut dapat dikatakan padat dan mungkin berupa hutan. Jika terdapat perbedaan yang sangat kecil antara kecerahan panjang gelombang RED dan NIR yang dipantulkan, maka tumbuhan mungkin jarang atau tipis dapat berupa padang rumput atau sawah masa vegetatif. Berdasarkan hal tersebut maka nilai NDVI digunakan untuk klasifikasi vegetasi berdasarkan dominasi tumbuhan.

Penelitian yang dilakukan oleh Myneni dan Williams (1994) menunjukkan bahwa nilai indeks vegetasi yang diperoleh dari persamaan NDVI berhubungan erat dengan fAPAR (fraction of Absorbed Photosynthetically Active Radiation). Sementara penelitian yang dilakukan Aparicio et al., (2002) dan Zavaleta et al., (2003) nilai NDVI berkorelasi kuat dengan LAI dan biomassa pada monokulture dan sensitif terhadap kandungan klorofil. Formula untuk menghitung nilai NDVI adalah:

$$
\text { NDVI }=\frac{\text { kanal NIR }(\text { band } 5)-\text { kanal Red }(\text { band } 4)}{\text { kanal NIR }(\text { band } 5)+\text { kanal Red }(\text { band } 4)}
$$

NDVI mempunyai rentang nilai dari $-1,0$ hingga 1.0. Awan, air, dan objek non-vegetasi mempunyai nilai NDVI kurang dari nol. Nilai yang mewakili vegetasi terdapat pada rentang 0.1 hingga 0.7. Jika nilai indeks lebih tinggi dari rentang ini berarti penutupan vegetasi tersebut lebih sehat (Lillesand dan Kiefer 1990). Nilai threshold masing-masing kelas vegetasi ditentukan dengan melakukan pengecekan lapang serta menggunakan aplikasi Google Earth dan Google Street View untuk ground truth check. Diagram alir penelitian dapat dilihat pada Gambar 4.

\section{HASIL DAN PEMBAHASAN}

\section{A. Analisis kerapatan vegetasi DKI Jakarta menggunakan NDVI}

Sebaran nilai kerapatan vegetasi di DKI Jakarta yang diperoleh berdasarkan analisis NDVI yaitu berada pada rentang -0.1970 hingga 0.6294 (Gambar 5). Tingkat kerapatan vegetasi berdasarkan nilai NDVI dapat dijadikan sebagai dasar pengkelasan sesuai dengan dominasi tumbuhan. Menurut Jaya (2014), permukaan vegetasi yang memiliki rentang nilai NDVI 0.1 
menunjukkan padang rumput dan semak belukar, nilai lebih dari 0.1 hingga 0.8 menunjukkan hutan hujan tropis, dan nilai NDVI mendekati +1 menunjukkan tutupan vegetasi. Pada penelitian ini, pengkelasan vegetasi dibagi atas vegetasi jarang (dominasi rumput), vegetasi sedang (dominasi semak/perdu), dan vegetasi lebat (dominasi tegakan pohon). Pada penelitian

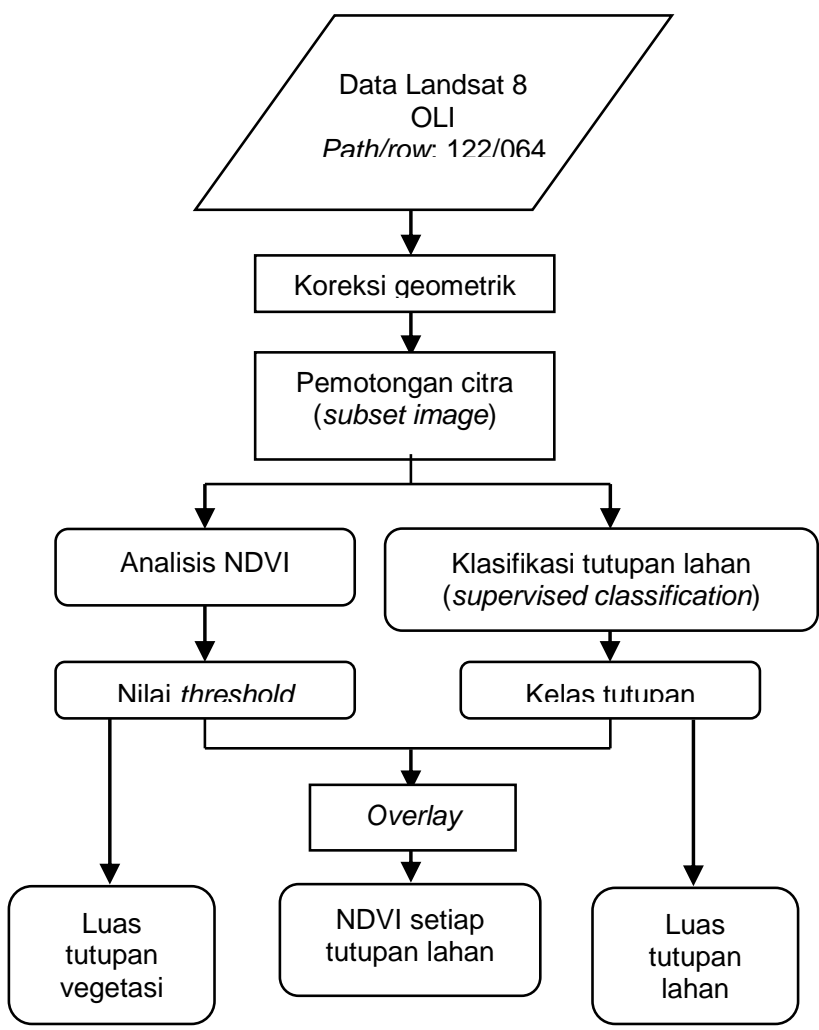

ini, nilai threshold vegetasi berada pada nilai

Gambar 4. Diagram alir penelitian

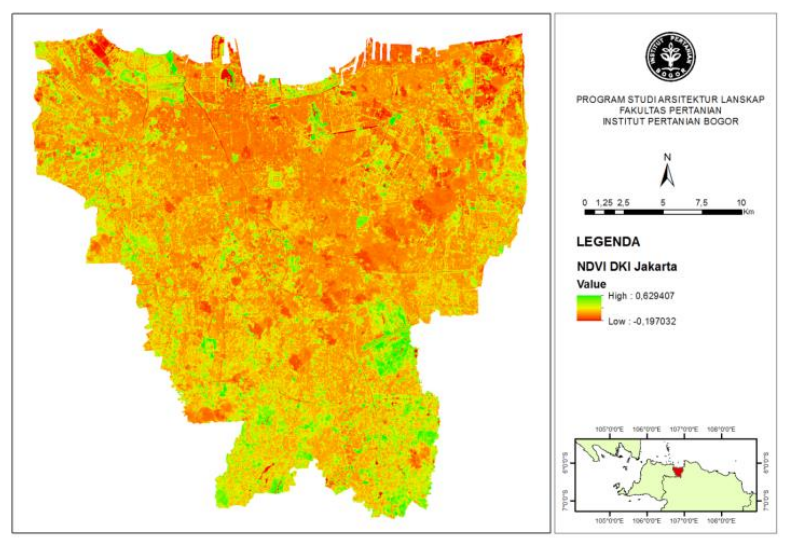

Gambar 5. Nilai NDVI DKI Jakarta 2014
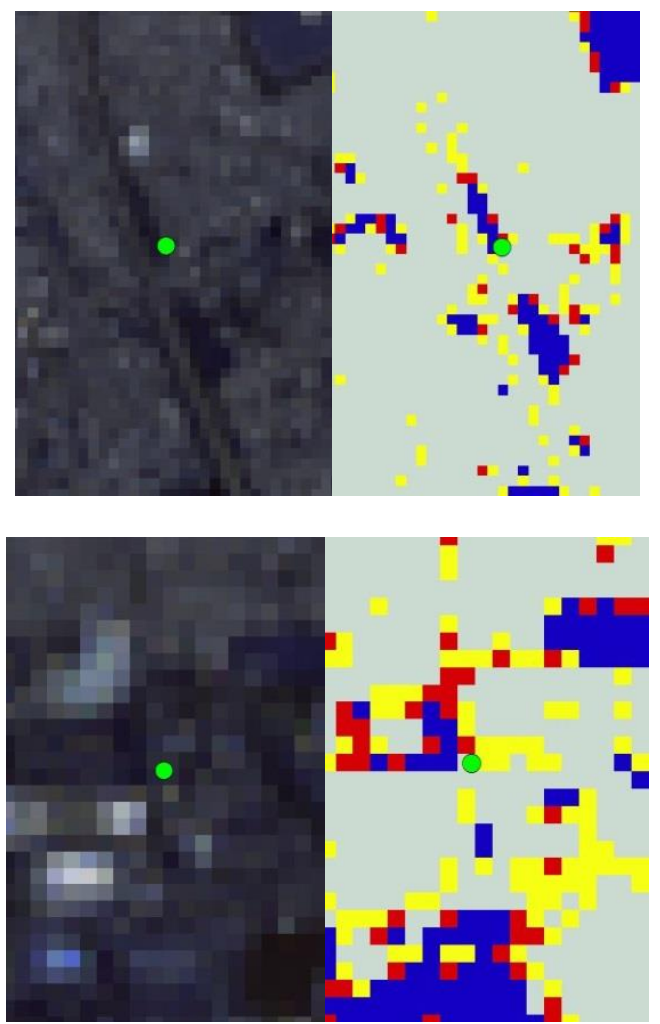

Gambar 6. Lokasi nilai threshold

(a) DN 0.2344 - vegetasi

(b) DN 0.2343 - non vegetasi

0.2343 (Gambar 6a). Nilai kurang dari angka tersebut diketahui sebagai lahan terbuka atau daerah terbangun dan bukan vegetasi (Gambar $6 b)$.

Tabel 1 menunjukkan klasifikasi kerapatan vegetasi DKI Jakarta tahun 2014. Kelas vegetasi jarang sebagian besar berupa rumput/lapangan golf/olahraga/area pemakaman/ persawahan terdapat pada rentang $0.2343-0.2813$ seluas $36.92 \%$ dari luas total vegetasi atau 4181.03 ha (6.31\% luas Jakarta). Kelas vegetasi sedang sebagian besar berupa semak/tanaman perdu/rumput tinggi terdapat pada rentang $0.2814-3143$ seluas $19.03 \%$ dari luas total vegetasi atau 2155.36 ha $(3.25 \%$ luas Jakarta). Kelas vegetasi lebat sebagian berupa tegakan pohon dari kanopi sedang hingga lebat/hutan kota/mangrove terdapat pada rentang 0.31440.6294 dengan luas $44.04 \%$ dari total luas vegetasi atau sekitar 4987.46 ha $(7.53 \%$ luas Jakarta). Dengan demikian, luas total tutupan vegetasi di DKI Jakarta adalah sebesar $17.10 \%$. Luas tersebut masih jauh dari batas minimal untuk sebuah kota, 
yaitu sebesar $30 \%$. Hal tersebut sejalan dengan penelitian yang dilakukan oleh Febrianti dan Sofan (2014) yang menunjukkan luas tutupan vegetasi di DKI Jakarta tahun 2013 sebesar 9\% dari luas seluruh wilayah DKI Jakarta. Peta analisis NDVI untuk wilayah DKI Jakarta berdasarkan tingkat kerapatan vegetasi ditunjukkan oleh Gambar 7.

Tabel 1. Nilai NDVI berdasarkan kerapatan

\begin{tabular}{|c|c|c|c|c|}
\hline No & $\begin{array}{l}\text { Kelas } \\
\text { vegetasi }\end{array}$ & $\begin{array}{l}\text { Nilai } \\
\text { NDVI }\end{array}$ & $\begin{array}{c}\% \\
\text { Veg.* }\end{array}$ & $\begin{array}{c}\text { Keteranga } \\
\mathrm{n}\end{array}$ \\
\hline 1 & Jarang & $\begin{array}{r}0.2343- \\
0.2813\end{array}$ & 36.92 & $\begin{array}{l}\text { Rumput/s } \\
\text { awah/pe } \\
\text { makaman }\end{array}$ \\
\hline 2 & Sedang & $\begin{array}{r}0.2814- \\
0.3143\end{array}$ & 19.03 & $\begin{array}{l}\text { Semak } \\
\text { /perd } \\
\mathrm{u}\end{array}$ \\
\hline 3 & Lebat & $\begin{array}{r}0.3144- \\
0.6294\end{array}$ & 44.04 & $\begin{array}{l}\text { Pohon } \\
\text { / huta } \\
\text { n kota }\end{array}$ \\
\hline
\end{tabular}

Total

100

.00

* dari luas total kelas vegetasi, sumber: hasil analisis (2016)

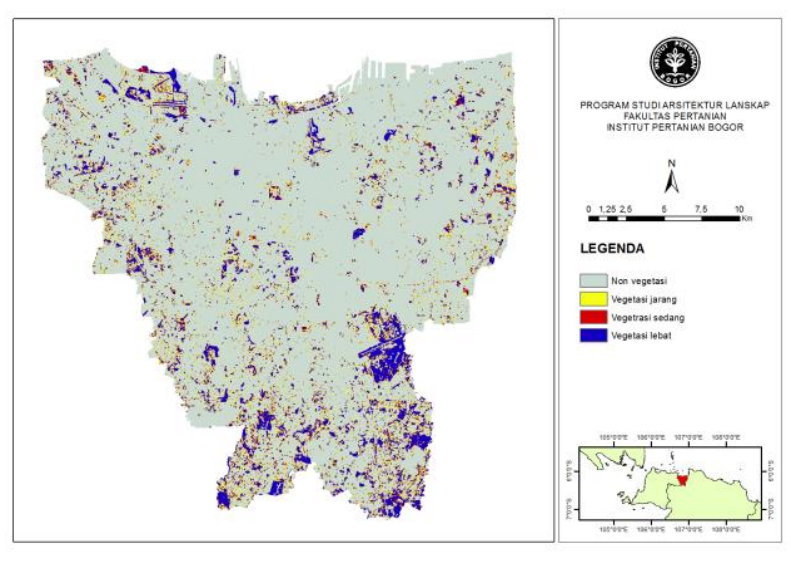

Gambar 7. NDVI DKI Jakarta 2014 berdasarkan tingkat kerapatan vegetasi

Berdasarkan peta tersebut dapat diketahui bahwa wilayah yang memiliki area hijau cukup luas berada di wilayah Kota Administrasi Jakarta Selatan dan Timur. Kota Administrasi Jakarta Barat dan Utara masih memiliki area hijauan meskipun dalam jumlah kecil. Kota Administrasi Jakarta Pusat merupakan wilayah yang memiliki luas hijauan terkecil. Deteksi tutupan vegetasi berdasarkan metode NDVI meliputi seluruh vegetasi, termasuk di dalamnya tajuk tegakan pohon, semak belukar, padang rumput dan area persawahan. Menurut Segah (1999), nilai-nilai NDVI dipengaruhi oleh beberapa faktor, di antaranya yaitu sudut matahari yang diindikasi memengaruhi reflektansi sinar merah dan inframerah, efek atmosfer, dan konsidi awan. Beberapa peneliti melaporkan kelembaban tanah menurunkan reflektansi dan meningkatkan ukuran-ukuran NDVI.

Menurut Nurbaya (2015 dalam Hashimoto et al., 2005) dari prespektif ekologi, target realistik untuk tutupan kanopi pohon di area perkotaan adalah $10 \%$ untuk menjaga keberlanjutan lingkungan kota. RTH dengan komponen utama vegetasi berperan meningkatkan daya dukung dan kualitas ekologi lingkungan (Wulandari et al. 2013). Tegakan pohon memiliki kemampuan lebih baik dan efektif mengurangi suhu di area perkotaan (Zain et al. 2015). Meskipun demikian, semua bentuk RTH membantu area perkotaan mengatasi pulau bahang (urban heat island), yaitu kondisi di mana suhu di daerah perkotaan lebih tinggi daripada daerah sekitarnya (Choi et al. 2012).

\section{B. Analisis penutupan lahan DKI Jakarta 2014}

Pada tahap ini dilakukan analisis klasifikasi penutupan lahan di DKI Jakarta untuk kemudian dibandingkan dengan hasil NDVI sehingga threshold NDVI dapat dipertanggungjawabkan. Penelitian ini menggunakan metode klasifikasi terbimbing Maximum Likelihood Classification (MLC) untuk menentukan tipe penutupan lahan di DKI Jakarta. Gambar 8 menunjukkan peta tutupan lahan menggunakan metode MLC. Tutupan lahan diklasifikasi dalam 6 kelas, yaitu sawah, RTH, lahan terbangun, lahan terbuka, badan air, serta awan dan bayangan dengan membuat training area sebagai kriteria pengelompokan kelas berdasarkan area of interest (AOI). Penentuan AOI dilakukan berdasarkan hasil pengamatan di lapangan dan Google Earth. Luas dan persentase kelas tutupan lahan disajikan pada Tabel 2. 


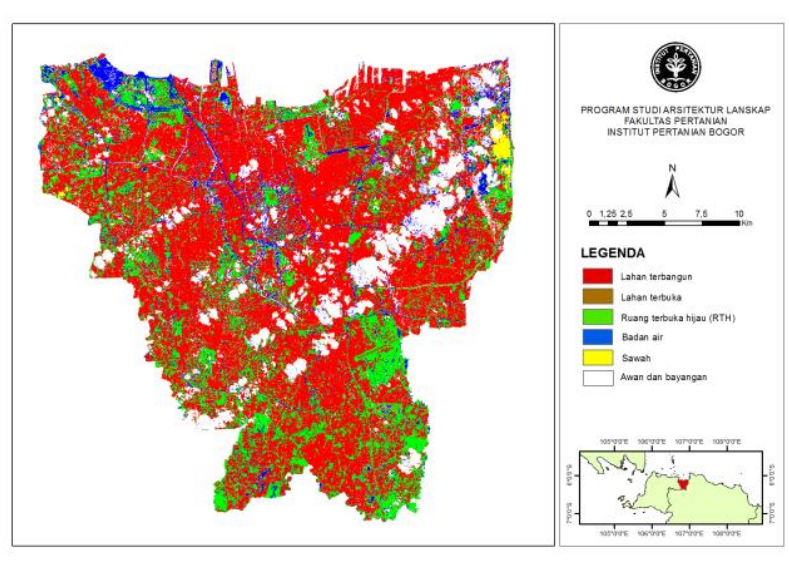

Gambar 8. Penutupan lahan DKI Jakarta 2014

Tabel 2. Luas dan persentase kelas tutupan lahan ${ }^{a}$

\begin{tabular}{|c|c|c|c|}
\hline $\begin{array}{l}\text { Kelas tutupan } \\
\text { lahan }\end{array}$ & $\begin{array}{l}\text { Kode } \\
\text { warna }\end{array}$ & luas (ha) & $\begin{array}{l}\text { Persentase } \\
(\%)\end{array}$ \\
\hline $\begin{array}{l}\text { Lahan } \\
\text { terbangun }\end{array}$ & & $36.693,29$ & 55,40 \\
\hline Lahan terbuka & & $1.183,85$ & 1,79 \\
\hline RTH & & $13.074,31$ & 19,74 \\
\hline Sawah & & 917,64 & 1,39 \\
\hline Badan air & & $5.477,71$ & 8,27 \\
\hline $\begin{array}{l}\text { Awan \& } \\
\text { bayangan }\end{array}$ & & $8.886,20$ & 13,42 \\
\hline Total luas & & $66.233,00$ & 100,00 \\
\hline
\end{tabular}

Uji separabilitas dari penciri kelas menunjukkan tingkat keterpisahan antar kelas. Hasilnya menunjukkan bahwa semua kelas yang didefinisikan memiliki separabilitas yang baik karena hampir seluruhnya memiliki nilai separabilitas lebih dari 1900 (Good). Dari hasil tersebut dapat disimpulkan bahwa pengambilan training area masing-masing tutupan lahan telah sesuai dan memiliki tingkat keterpisahan yang baik. Hal ini tidak terlepas karena kelas tutupan lahan yang dipergunakan tidak terlalu banyak atau kompleks. Setelah proses klasifikasi, dilakukan perhitungan tingkat akurasi hasil klasifikasi. Tingkat akurasi diperoleh dari proses evaluasi kontingensi terhadap file penciri kelas yang telah dilakukan proses klasifikasi terbimbing MLC untuk producer's accuracy (PA) dan user's accuracy (UA). Hasil uji akurasi menunjukkan nilai Overall Accuracy (OA) sebesar 89.45\% dan Kappa Accuracy (KA) sebesar 81.27\%.

Tabel 3 memperlihatkan nilai NDVI pada setiap kelas lahan. Hasil overlay nilai NDVI dengan peta penutupan lahan DKI Jakarta menunjukkan terdapat kesalahan pada hasil/ pemasukan data. Sebagai contoh, kelas lahan terbangun memiliki nilai NDVI maksimum 0,4389 yang seharusnya nilai tersebut merupakan nilai NDVI untuk kelas vegetasi. Demikian pula pada kelas RTH yang memiliki nilai minimum -0,0612 yang seharusnya termasuk pada kategori non vegetasi. Berdasarkan perolehan nilai tersebut, maka dapat disimpulkan untuk penentuan sebaran vegetasi/RTH akan lebih baik jika dilakukan dengan metode indeks vegetasi daripada pola penutupan lahan. Hal ini untuk mengurangi kemungkinan terjadinya kesalahan pengkelasan jenis penutupan lahan, sesuai dengan penelitian yang dilakukan oleh Febrianti dan Sofan (2014).

Tabel 3. Nilai NDVI setiap kelas tutupan lahan DKI Jakarta 2014

\begin{tabular}{|c|c|c|c|c|}
\hline No. & $\begin{array}{l}\text { Kelas } \\
\text { tutupan } \\
\text { lahan }\end{array}$ & Min & Max & Rataan \\
\hline 1 & $\begin{array}{l}\text { Ruang } \\
\text { terbuka } \\
\text { hijau }\end{array}$ & -0.0612 & 0.6241 & 0.28145 \\
\hline 2 & Sawah & -0.1153 & 0.3182 & 0.10145 \\
\hline 3 & $\begin{array}{l}\text { Lahan } \\
\text { terbuka }\end{array}$ & -0.0843 & 0.3345 & 0.1251 \\
\hline 4 & $\begin{array}{l}\text { Lahan } \\
\text { terbangun }\end{array}$ & -0.1691 & 0.4389 & 0.1349 \\
\hline 5 & Badan air & -0.1784 & 0.5128 & 0.1672 \\
\hline 6 & $\begin{array}{l}\text { Awan dan } \\
\text { bayangan }\end{array}$ & -0.197 & 0.4699 & 0.13645 \\
\hline
\end{tabular}

\section{SIMPULAN DAN SARAN}

\section{Simpulan}

Berdasarkan penelitian yang dilakukan maka diperoleh kesimpulan sebagai berikut.

1. Metode NDVI yang diterapkan pada citra Landsat 8 dapat digunakan untuk memperoleh informasi mengenai tutupan vegetasi dan persentase tutupan vegetasi di wilayah penelitian. 
2. Berdasarkan hasil yang didapatkan, nilai threshold vegetasi berada pada nilai $\mathrm{DN} \geq 0.2343$. Nilai kurang dari angka tersebut diketahui sebagai lahan terbuka atau daerah terbangun dan bukan vegetasi. Kelas vegetasi jarang sebagian besar berupa rumput/lapangan golf/olahraga/area pemakaman/persawahan terdapat pada rentang $0.2343-0.2813$ seluas $36.92 \%$ dari luas total atau 4181.03 ha (6.31\% luas Jakarta). Kelas vegetasi sedang sebagian besar berupa semak/tanaman perdu/rumput tinggi terdapat pada rentang $0.2814-3143$ seluas $19.03 \%$ dari luas total vegetasi atau 2155.36 ha (3.25\% luas Jakarta). Kelas vegetasi lebat sebagian berupa tegakan pohon dari kanopi sedang hingga lebat/hutan kota/mangrove terdapat pada rentang 0.3144-0.6294 dengan luas $44.04 \%$ dari total luas vegetasi atau sekitar 4987.46 ha $(7.53 \%$ luas Jakarta). Wilayah yang memiliki area hijau cukup luas berada di wilayah Kota Administrasi Jakarta Selatan dan Timur. Kota Administrasi Jakarta Barat dan Utara masih memiliki area hijauan meskipun dalam jumlah kecil. Kota Administrasi Jakarta Pusat merupakan wilayah yang memiliki luas hijauan terkecil.

3. Untuk menentukan sebaran vegetasi/RTH akan lebih baik jika dilakukan dengan metode indeks vegetasi daripada pola penutupan lahan. Hal ini untuk mengurangi kemungkinan terjadinya kesalahan pengkelasan jenis penutupan lahan.

\section{Saran}

Adapun saran terkait penelitian ini antara lain sebagai berikut.

1. Diperlukan analisis lebih lanjut menggunakan citra dengan resolusi tinggi untuk menghasilkan data yang lebih akurat.

2. Diperlukan upaya peningkatan penyediaan dan strategi pengelolaan RTH yang baik dan terpadu untuk menjaga keseimbangan kota serta memenuhi amanat UU RI No. 26 Tahun 2007 yang mensyaratkan RTH pada wilayah kota paling sedikit $30 \%$.

3. Diperlukan adanya kerjasama dan peran serta pemerintah, swasta, dan masyarakat untuk menjaga, mengelola, dan mengoptimalisasi
RTH guna untuk menciptakan lingkungan kota yang sehat dan berkelanjutan.

\section{DAFTAR PUSTAKA}

Aparicio N, Villegas D, Araus JL, Casadesús J, Royo C. 2002. Relationship between growth traits and spectral vegetation indices in durum wheat. Crop Sci. 42:1547-1555.

Choi HA, Lee WK, Byun WH. 2012. Determining the effect of green spaces on urban heat distribution using satellite imagery. Asian Journal of Atmospheric Environment 6(2):127-135.

Dwihatmojo, R. 2010. Ruang terbuka hijau yang semakin terpinggirkan. http://www.bakosurtanal.go.id/artikel/show/ruang-terbukahijau-yang-semakin-terpinggirkan (diakses 11 Februari 2017).

Febrianti N, Sofan P. 2014. Ruang terbuka hijau di DKI Jakarta berdasarkan analisis spasial dan spektral data Landsat 8. Seminar Nasional Penginderaan Jauh 2014: 499-504.

Hashimoto H, Natuhara Y, Morimoto Y. 2005. A habitat model for Parusmajor minor using a logistic regression model for the urban area of Osaka, Japan. Landscape and Urban Planning 70 (3-4): 245-250.

Hung, T. 2000. MODIS Application in Monitoring Surface Parameters. Institute of Industrial Science. Tokyo: University of Tokyo.

Jaya, INS. 2014. Analisis Citra Digital. Bogor: IPB Press.

Lillesand TM, Kiefer RW. 1997. Penginderaan Jauh dan Interpretasi Citra. Yogyakarta: Gadjah Mada University Press.

Martiyanti, E. 2016. RTH di DKI capai 9.896,8 Hektare. http://www.jakarta.go.id/v2/ news/2016/10/rth-di-dki-capai-9.8968hektare\#. WKKSx2997Dc (diakses 22 Desember 2016). 
Myneni RB, Williams DL. 1994. On the relationship between FAPAR and NDVI. Remote Sensing of Environment 49: 200-211.

Nurbaya, A. 2015. Distribusi Tipologi Kepemilikan RTH DKI Jakarta Menggunakan Teknik Remote Sensing Citra Satelit Resolusi Tinggi [Tesis]. Bogor: Institut Pertanian Bogor.

Segah, H. 1999. Kajian akurasi citra Landsat-TM yang didukung citra NOAA-AVHRR dalam mendeteksi perubahan penutupan lahan areal proyek pengembangan lahan gamhut (PLG) sejuta hektar di Propinsi Kalimantan Tengah [Tesis]. Bogor (ID): Institut Pertanian Bogor.

Undang-Undang RI No. 26 Tahun 2007 tentang tentang Penataan Ruang.

Wulandari LD, Rachmawati TA, Ramdlani S. 2013. Hirarki peran ragam ruang terbuka hijau (rth) dalam peningkatan kualitas ekologis lingkungan pusat Kota Malang [Laporan Akhir PUPT]. Malang: Universitas Brawijaya.

Zain AFM, Permatasari PA, Ainya CN, Destriana N, Mulyati DF, Edi S. 2015. Monitoring The detection of urban open space at Jakarta, Bogor, Depok, and Tangerang-Indonesia by using remote sensing technique for urban ecology analysis. Procedia Environmental Sciences 24:87-94.

Zavaleta ES, Thomas BD, Chiariello NR, Asner GP, Shaw MR. 2003. Plants reverse warming effect on ecosystem water balance. PNAS 100(17): 1892-1893. 